\title{
SEMANTICS AND STRUCTURE OF COMPLEX WORD COMBINATIONS IN THE CONTEMPORARY KARAKALPAK LANGUAGE
}

\author{
Opaeva Raygul Aymanovna \\ A lecturer for the Department of Karakalpak linguistics at Nukus State Teachers' Training \\ Institute after Ajiniyaz.
}

Article DOI: https://doi.org/10.36713/epra4733

\begin{abstract}
The article deals with semantics and structure of complex and composite words appearing nowadays in the modern Karakalpak language.

Complex words are formed from two or more words and denote a broad concept. Combination of their components are combined by meaning as fixed combinations and they perform a function of one member of a sentence.
\end{abstract}

KEY WORDS: Composite terms, thematic classification, lexical-semantic classification, structure, paired words, abbreviated words, borrowed composite words, tracing.

\section{DISCUSSION}

Complex words, unlike phrases, act as wholeformed units and it is impossible to insert another word between its components.

In the modern Karakalpak language formation of complex words in the recent decade has become a very productive way of word formation. If we consider them from a semantic point of view, they encompass words that enter various spheres of the life. Especially actively complex words are used in journalistic and scientific styles.

Complex words of the Karakalpak language have hardly been studied so far. Phraseological, syntactically indecomposable combinations have also not been studied. Some studies related to this aspect are fragmented. In this connection, our chosen subject of investigation remains topical to this day.

The novelty of the work lies in the fact that for the first time an attempt is made to study complex words and phrases in structural, thematic and lexicalsemantic aspects.

The practical significance of the work is determined by the fact that its results can be used in the development of lectures and seminars, as well as in the compilation of dictionaries.
Based on the empirical collected data modern complex words of the modern Karakalpak language were divided from a semantic point into the following types:

I. Composite terms related to the socioeconomic sphere of life бәнтликке көмеклесиу орайы (center for employment), бес күнлик жумыс хәптеси (five-day working week), банк aydumu (bank audit), банк фолиалы (Bank branch), банк есапбети (account Bank), биржа mовары (commodity exchange), киши бизнес (smaller business), экономикалық реформа (economic reform), турақ жай фонды (housing fund), төлеу терминаллары (payment terminals), еркин базар (free market), киши кәрхана ( smaller enterprise), қоспа кәрхана (joint venture), uри оңлаў жумыслары (work on capital construction), пластик карточка (plastic card), исбилерменлик субъектлери (entrepreneurial entity), хожалық жүритиушии субъект (economic entity), аксил реклама (axial advertising), etc. For example, Хәзирги ууақытmа исбилерменлик субъектлери тәрепинен пластик карточкалар хәм төлеў терминалларынан пайдаланыў хәм де 


\section{EPRA International Journal of Research and Development (IJRD) \\ Volume: 5 | Issue: 7 | July 2020

\author{
- Peer Reviewed Journal
}

тутыныўшыларға усы төлем түри арқалы хызмет көрсетиў кеңнен өзлестирилмекте - At present entrepreneurial entities actively practice such new payment technologies in their work with customers as plastic cards and payment terminals (Erkin Qaraqalpaqstan, 10.09.2009).

By the structure the complex words are divided into the following types:

1. Noun + noun: мийнет

биржасы (labor exchange), банк фрилиалы (bank branch), банк аудumu (bank audit), пластик карточка (plastic card dot), etc.

2. Adjective + noun: киши кәрхана (smaller enterprise), қоспа кәрхана (joint venture), киши бизнес (smaller business), еркин базар (free market), etc.

3. Action noun + noun: төлеў терминаллары ( payment terminals), etc.

4. Noun + action noun + noun: бәнтликке көмеклесиў орайы (employment assistance center), хожалық жүритиўши субъект (economic entity), etc.

5. Adjective + action noun + noun: upu оңлаў жумыслары (work on capital construction), etc.

6. Numeral+action noun + noun: бec күнлик жумыс хәптеси (five-day working week), etc.

II. Composite terms formed in connection with changes in the field of medicine: репродуктив саламатлылық (reproductive health), Республикалық көп тармақлы медициналық орай (Republican diversified medical center), бас шыпакер (head physician), қыстаўлы медициналық жәрдем (emergency medicine), орта буўын медицина хызметкерлери (midlevel medical personnel) стационар емлеў (inpatient treatment), etc. For example: Оларда профрилактикалық көриктен өтип ракқа қарсы гүресиў жумыслары күшли алып барылады, халқы өзлерине, ден-саўлығына айрықша итибар менен қарайды. - Their patients undergo prophylactic examination, they carry out intensive work to fight against cancer, their patients pay a big attention to themselves and their health (Qaraqalpaqstan. № 5-6).

These complex words by their morphological structure are divided into the following types: adjective+noun: профилактикалық көрик (preventive examination), стационар емлеў (inpatient treatment), etc. noun + noun: бас шыпакер (chief physician), and so on; adverb+noun: тез жәрдем (ambulance), etc.
III. Composite terms formed due to changes in the judicial-legal sphere: адам саўдасы (human trafficking), нәшебентлик затлар (narcotic staff), реакцион-диний топарлар (reactionary religious groups), адвокатлар фрирмасы (advocacy office), адвокат этикасы (lawyer's ethics ), бажыхана транзити (customs transit), газли қураллар (gas weapons), хаяллар жынаятшылығы (female crime), криминалистлик техника (forensic technology), улыўма мүлк (common property), бир адамлық камера (single cell), etc. For example, Адам саўдасы - инсан қәдир-қымбатына қәўип салатуғын трансмиллий, уйымласқан жынаятшылық көринислериниң бири есапланады - Human trafficking is considered one of the types of transnational organized crime threatening honor and dignity of the whole mankind (Gárezsizlik hám nızam, 27.02.2010).

Consideration of their structure reveals the following types:

1. Noun+ noun: адам саўдасы (human trafficking), адвокат этикасы (lawyer's ethics ), адвокатлар фрирмасы (advocacy office), etc.

2. Adjective + noun: газли қураллар (gas weapons), нәшебентлик затлар (narcotic staff), etc.

3. Pronoun+ noun: улыўма мүлк (common property), etc.

4. Numeral + noun: бир адамлық камера (single cell), etc.

IV. Composite terms formed due to development of mass media: цифрралы телевидение (digital television), медиа базар (media market), интернет материаллары (Internet materials), мәлимлеме - ресурс орайы (information-resource center), газета тиражы (newspaper circulation), журналистлик интуиция (journalistic intuition), ғалаба хабар қураллары (mass media), цифралы тюнер (digital tuner), etc.

If we consider these examples by the morphological structure, the complex will have the following types:

1. Noun + noun: газета тиражы (newspaper circulation), мәлимлеме- ресурс орайы (information-resource center), etc.

2. Adjective + noun: цифралы

телевидение (digital TV), журналистлик интуиция (journalistic intuition), еtc.

3. Pronoun + noun: ғалаба хабар қураллары (mass media), etc.

V. Composite terms formed due to changes in the field of communication: уялы телефон (cell 


\section{EPRA International Journal of Research and Development (IJRD)}

Volume: 5 | Issue: 7 | July 2020
- Peer Reviewed Journal phone), фраксимиллик байланыс (facsimile communication), байланыс операторы (telecom operator), мобиль телефон (mobile phone), почта жөнелтпелери (postal transfers), пул жөнелтпелери (money transfers), исеним телефоны (helpline), кең полосалы сымсыз байланыс (broadband wireless), сим карта (sim card), etc. For example, Электр байланысының тийкарғы түрлери: телефон, телеграф, фраксимиллик байланыс, мағлыўматларды жеткерип бериў, видеотелефон байланыслары болып табылады. - The main types of electrical communications are telephone, telegraph, facsimile, information delivery and video telephony (Erkin Qaraqalpaqstan, 23.03.1995).

VI. Compound terms formed due to changes in the field of education: мәмлекетлик грант (state grant), mecm сынақлары (testing forms), мәмлекетлик тест орайы (state test center), магистратура бөлими (magistracy department), магистр дәрежеси (master's degree), титул қағазы (title page), қосымша контракт (alternative contract), жуўмақлаўшы қадағалаў (final assessment), технологиялық карта (technological map), etc. For example: Өзбекстан Республикасы Қаржы министрлиги, 2010/ 2011-оқыў жылында мәмлекетлик грантлар тийкарында бакалаврият, магистратураға қабыл етиўдиң тастыйықланған квоталарына муўапық қәлиплесип атырған студентлер контингентин есапқа ала отырып, бюджеттен зәрурли қаржылар ажыратылыўын тәмийинлесин). - The Ministry of Finance of the Republic of Uzbekistan in the academic year of 2010-2011 in accordance with the approved quota for admission to a master and bachelor level study on the basis of a state grant, taking into account the formed student contingent will ensure the allocation of necessary funds from the budget (Qaraqalpaqstan jaslar1, 3.06.2010).

The structure of the composite terms formed due to changes in the field of education is as follows:

1. Noun + noun: мәмлекетлик тест орайы (state testing center), mecm сынақлары (testing forms), магистр дәрежеси (master's degree), титул қағазы (title page), etc.

2. Noun + action noun: халық билимлендириў бөлими (Department of Public Education), etc.

3. Adjective+action noun: жуўмақлаўшы қадағалаў (final assessment), etc...

One of the most popular types of composite words is paired words. They indicate a certain degree of transformation of ordinary words into a composites being used in pairs. About paired words which are one of the types of composite words, E. I. Ubryatova [3, p. 301] in her work "Paired Words in the Yakut Language" indicates different types of paired words and determines their basic originality.

1. The authour points out that in the Turkic languages there are two ways of pairing words: the way of pairing and the way of matching. In both cases, the grammatical indicators of change and formation of the word belong to the last (second) component of paired words. The first method is characteristic of all the Turkic languages, and the second method is characteristic of the Old Turkic languages. For example: In the Yakut language uŭeаға (parents), ийем-ағам (my parents).

N. A. Baskakov $[1$, p. 2, 17] in his work "The Karakalpak language" considers complex nouns as paired words, i.e. words that consist of two elements forming pairs reinforce the meaning or indicate collectivity, generalization. For example,

1. Words denoting collectivity: mёбeтёбе-таўлар (high-high mountains), ойынойын-ойыншықлар ( funny-funny toys ).

2. Words denoting generality: ер-джюген (saddle-bridle), юстки-басы (clothing), etc .

Paired word of the Karakalpak language are widely regarded in a special study and in some articles of A. Najimov [2, p. 32, 3-29; 63, 122-128].

In a recent time paired words due to changes in the society and development of science and technology have been widely used in press. For example, жанылғы энергетика (fuel energy), төлем-контракт (рау-contract), саўдаэкономикасы (trade economy), илимий-әмелий (scientific and practical), илимий-изертлеў (scientific research), семинар-кеңес (training seminar), арақ-шарап (vodka and wine goods), суд-хуқық (court and law), саўда-санаam (trade and industry), мәлимлеме-таллаў (analytical and identifying), аўыллық-шыпакерлик пункт (rural medical center), нефоть-газ (oil and gas), санитария-эпидемиология (sanitationepidemiology), etc. For example, Ha научнопрактической конференции участвовал Председатель Верховного Совета Республики Каракалпакстан Б. Нурабуллаев. - The scientific and practical conference went off in association of the Chairman of the Supreme Council of the Republic of Karakalpakstan B. Nurabullaev (Erkin Qaraqalpaqstan, 4.12.2010).

The most productive complex words are abbreviated words. Expansion of public services has a certain impact on language development.

Abbreviated complex words are formed from two or more abbreviated words. The process of 


\section{EPRA International Journal of Research and Development (IJRD) \\ Volume: 5 | Issue: 7 | July 2020

abbreviation is characteristic of nouns only. Therefore, complex words are the main source in their formation. For example, $\Theta_{3} P$ (the Republic of Uzbekistan), ӨзА (Agency of Uzbekistan), ӨзХДП (People's Democratic Party of Uzbekistan), etc.

In the Karakalpak language abbreviated words were adopted primarily in the Russian version: RSFSR, sovnarkom, revkom, GPU, etc. Afterwards some words were adopted in the form of tracing. In the Karakalpak language tracing of abbreviated complex words has become a productive phenomenon since 1960.

Abbreviated complex words that are in current use are different by structure and way of formation. Basically they are divided into three groups:

1. Abbreviated complex words borrowed from other languages without changing the structure. Such the words in the Karakalpak language cannot be divided into component parts since they will not correspond to the initial accepted form. For example : UNESCO, FIDE, etc.

2. Abbreviated complex words formed by way of tracing some borrowed words. Such print tracing is somewhat productive formation. For example: OON (UN), SShA (USA). etc.

3. Abbreviated complex words formed from original Karakalpak words. There are very few words of such sort in the language and they are extremely unproductive. For example, ХББ (public education department), БКО (employment assistance center), ЖШЖ (limited liability company), etc.

Thus, in conclusion we need to point out hereby that in general complex words of the Karakalpak language have recently begun to develop productively in connection with development of the society, science and technology.

\section{REFERENCES}

1. Baskakov N.A. The Karakalpak Language. II volume. Phonetics and morphology (Parts and word formation). Moscow, 1952.

2. Najimov A.N. Methods of forming paired and paired-repeated words in the Karakalpak language. Abstract of Cand. Diss. Nukus, 1971.

3. Ubryatova E. And Paired words in the Yakut language. M.-L., 1948. 